\title{
Iranian EFL teachers and learners' perceptions of grammar instruction and corrective feedback
}

\author{
Mohammad Mohammadi and Mohammad Hosssein Yousefi ${ }^{*}$ (I)
}

\author{
* Correspondence: mhh.yousefi@ \\ gmail.com \\ Department of English Language, \\ Bonab Branch, Islamic Azad \\ University, Bonab, Iran
}

\begin{abstract}
This paper addresses Iranian English as Foreign Language teachers and learners' perceptions of explicit grammar instruction and corrective feedback and the effect of language background on learners' perceptions of explicit grammar teaching. The research background indicates that explicit instruction and corrective feedback can play a significant part in the second language development. However, the extent to which their perceptions of the variables in the light of linguistic differences and learners' language proficiency levels differ towards them remains a gap in the literature. To fill it, the study was conducted involving totally 360 Iranian Azeri and Persian EFL learners along with 100 teachers possessing the similar language backgrounds. Both groups received a validated questionnaire of Perceptions towards grammar instruction and corrective feedback. The respective data were analyzed non-parametrically such that the results revealed both the learners and the teachers held significantly different perceptions towards the grammar instruction. The differences mainly attributed to their language backgrounds affecting the way they perceive the world including education. The Persian EFL learners held more positive views than the Azeri EFL learners. They also hold a more neutral view. The findings of the present study contribute to the field of second language teaching. The findings may improve our understanding of grammar development and corrective feedback and enable us to incorporate effective methods of teaching grammar in the EFL classrooms through considering learners' linguistic background and the context in which the target language is being taught.
\end{abstract}

Keywords: Corrective feedback, Explicit grammar instruction, Perception

\section{Introduction}

Obviously, the history of second/foreign (L2/FL) language acquisition "is characterized by a growing interest in general research on the mental images, thoughts, and processes L2/FL learners and their teachers employ in their careers, respectively" (Abbasian, 2009). Their mental processes provide "interpretative frames" used to understand and approach their own careers (Richards, 1996, p.1). Both groups, in this process, develop their own personal principles functioning like rules for the best behavior or maxims. Among the variables determining their interpretative frames, their beliefs or perspectives about learning in general and language learning in particular, referring to

(c) The Author(s). 2019 Open Access This article is distributed under the terms of the Creative Commons Attribution 4.0 International License (http://creativecommons.org/licenses/by/4.0/), which permits unrestricted use, distribution, and reproduction in any medium, provided you give appropriate credit to the original author(s) and the source, provide a link to the Creative Commons license, and indicate if changes were made. 
opinions they hold about various aspects of language learning have recently been the major focus of the attention (Horwitz, 1987a in Diab, 2006). It is also believed that such beliefs are linked with many effective variables and language teaching-learning strategies (Wenden, 1986, cited in Abbasian, 2009). Their belief systems are interpretable under the framework entitled "Hidden Agenda" (Nunan, 1989). Nunan's notion may "lead learners to concentrate on specific language points or areas, e.g., formal language points rather than communicative purposes of a lesson, signifying some sort of conflicting conceptions of various language learning activities such as: corrective feedback, learner self-discovery of errors, and pair work. He has found mismatch between learners' and teachers' responses on all but one of ten different classroom activities. That is why the major problem is whether learners' perceptions of the prominence of various classroom activities are the same as those of the teachers who are initiating them" (Abbasian, 2009). Huang Jing in his seminal article (2006) tried to prove that learners' resistance in metacognitive resistance is partly due to a mismatch between the goals and expectations on the part of the teachers and learners' beliefs. According to him, "learner resistance is a function of tension and conflicts in the learners and teachers' agenda. Their conflicts are basically witnessed in learners' and teachers' different perceptions, learning and instruction, lesson purposes, classroom activities and learning outcomes" (Jing, 2006, p.99). Nunan (1995) tries to make association between such an agenda mismatch and mismatch of learning and instruction.

A well-known earlier study (Frohlich et al., 1985) looked at the differences between teachers in their orientations to communicative language instruction. This and similar studies indicate that teachers hold a variety of beliefs and understandings. Mangubhai et al. (1998) put teacher had understanding and beliefs about CLT that differed from those of CLT researchers and theorists. These kinds of mismatches can hold true with respect to all areas and types of instruction, correction strategies, and also to all aspects of language construct including skills and components and the approach based on which they should be taught and learned. However, grammar instruction and the way required feedback is supposed to be given to the respective errors are of significance generality due to the former play in the process of L2/FL acquisition.

Grammar instruction (whether explicitly or implicitly) and corrective feedback have been controversial issues in teaching and learning a new language since the last quarter of the twentieth century with the emergence of Stephan Krashen's comprehensible input theory (1982), though the traces of the debate could be somehow pursued in the GTM, and ALM as they relied on the explicit and implicit modes of teaching grammar, respectively. Relying on Noam Chomsky's contention "grammar competence develops naturally", Krashen stressed on the idea that grammar and correction seem irrelevant because according to an "innate program" grammar is acquired, and not through instruction. This perspective was taken to imply that correction was unnecessary (Hudson, 2001, p.1). These views were imported into SLA theory in the 1980's largely through the work of Stephen Krashen who argued that competence (in Chomsky's sense) in a second language is acquired implicitly and only by means of comprehensible input (Krashen, 1982, p. 10).

In the 1990's Schmidt presented his "noticing theory" and argued that learning / acquisition of grammar heavily relies on the explicit, well-clarified knowledge of grammar. Swain (2005) with her output theory challenged Krashen's perspective as she had earlier proposed 
"...we wish to make the case that sometimes, under some conditions, output facilitates second language learning in ways that are different from, or enhance those of input" (Swain \& Lapkin, 1995, p. 371). Swain (2005) hypothesizes that "output has a noticing or triggering function, a hypothesis testing function and a meta-linguistic function" (p. 474). Feedback based corrective feedback should be most operative to the hypothesis testing function, for she suggests that learners experiment as they produce language, seeking confirmation for their hypotheses. She goes on to argue that "if the learner's hypothesis is wrong in a particular instance then negative feedback in the form of explicit correction, confirmation checks and clarification checks can make the discrepancy with target forms clear" (Swain, 1985, p. 246). Here she is referring specifically to oral correction but it is reasonable to assume the same principles would apply to correction of written output. It seems, therefore, that grammar instruction and correcting the learners' errors have come back to the scene to prove that teaching and learning a foreign language require more than just being exposed to the language materials even in the meaningful and purposeful input or intake.

Perceptions of the proponents of the Audio-lingual approach of the errors and corrective feedback revealed that learners inevitably would commit different types of errors and correcting them would be harmful and hindering. Concerning the position of grammar instruction and corrective feedback, Schulz (2001) mentions three different groups as follows:

"there are those scholars who believe that grammar instruction and corrective feedback are necessary in adolescent and adult classroom language learning (Hammerly, 1985; Higgs \& Clifford, 1982; Valette, 1991); there are those who believe that-if done appropriately-grammar instruction and corrective feedback can be helpful in enhancing and accelerating adolescent and adult FL learning (Doughty \& Williams, 1998; Lalande, 1982; Lightbown, 1998; Long \& Robinson, 1998; Lyster, Lightbown, \& Spada, 1999); and there are those who see little if any benefit in devoting valuable classroom time to analysis and practice of particular grammatical patterns or to providing feedback to learners' errors (Hammond, 1988; Krashen, 1985; Semke, 1984; Terrell, 1977; Truscott, 1999)". (p. 245).

Grammar instruction and corrective feedback are entangled and employing a suitable method to deal with teaching grammar requires the implication of certain corrective feedback techniques. Indeed corrective feedback is a delicate task and according to Hendrickson (1978, p. 290) there are some questions about errors which go as follows: “1) should learners' errors be corrected? 2) When should learners' errors be corrected? 3) Which errors should be corrected? 4) How should errors be corrected? 5) Who should do the correcting? Some of the above-mentioned questions may be raised to grammar instruction." For example, how should be grammar taught? When should explicit or implicit grammar be instructed?

\section{Explicit instruction}

Katayama (2007) rightly puts that learners differ in terms of their learning styles and preferences for instructional practices. Then, it is more likely that teachers and learners' perspectives and perceptions do not match. Horwitz (1988) also notes that a lot of teachers have to contend with learners who complain if teachers do not correct their every oral error. Although the idea of explicit grammar has been recently attracted a 
lot of attention and is being considered as one of the prime possibilities in the second language learning and development, it seems that the EFL learners do not agree upon the perception they take towards explicit grammar instruction in learning English. Some learners take a positive view and some others take a negative view towards the explicit use of grammar, and some others may hold a more neutral view. Lingli and Wannaruk (2010) present that explicit instruction outperforms the implicit type. Eslami-rasekh and Fatahi (2004) also believe that in the foreign language context; the situation the learners are involved in [like the one in Iran], explicit instruction takes further steps to pave the way for the enrichment of pragmatic knowledge of the learners. In another line of research, Borg (2006) puts forward the idea that teachers do indeed have a set of complex belief systems about the teaching grammar. It is also believed that "teachers appear to see grammar as important for their learners and to have a sophisticated understanding of the problems and issues involved in its teaching" (Burgess \& Etherington, 2002, p.450).

In a study Barnard and Scampton (2008) came to the result the majority of the teachers (71.90\%) agreed or strongly agreed that the learners like the grammatical points to be presented explicitly and they believed that the lack of explicit teaching of grammar leaves the learners feeling insecure. This is in line with what Schmidt (1994) stresses as the crucial role of explicit grammar formation in the second language development.

Regarding the effect of formal instruction and corrective feedback on improving learners' accuracy in using the target language, positive results are reported by Lightbown and Spada (1999). They examined the effects of corrective feedback and form-focused instruction on SLA, which suggested that overall language skills are best developed through meaning-based instruction in which form-focused activities and corrective feedback are provided.

Nevertheless, it seems that the EFL learners do not agree upon the perception they take towards explicit grammar instruction in learning English. Borg (2006) holds in some classes are more willing to employ explicit teaching and in some other ones they might prefer to employ implicit teaching. Witnessing teachers with different and even opposing views towards employing corrective feedback has been recorded in the literature as something usual (Barnard \& Scampton, 2008; Borg \& Bums, 2008; Burgess \& Etherington, 2002). Hamouda (2011) points out that while teachers and learners share such common views about the importance of explicit teaching of grammatical points, there exist considerable discrepancies as to the techniques of explicit teaching and its nature (Diab, 2006) also found various discrepancies between EFL instructors' and learners' preferences for explicit instruction of grammar and its error- correction techniques. Such differences can result in unsatisfactory learning outcomes (Riazi \& Riasati, 2007; Katayama, 2007).

\section{Corrective feedback}

On the significance of corrective feedback, Hyland and Hyland (2006) believe that "it is difficult to draw any clear conclusions and generalizations from the literature as a result of varied populations, treatments and research designs" (p. 84). On the contrary, Krashen (1982) is suspicious and pessimist towards corrective feedback when he (1982) referred to corrective feedback as a serious mistake since it persuades learners to defend from themselves and because it only assists the development of learned knowledge and plays no role in acquired knowledge. Whereas, Long (1996) considered corrective feedback in the form 
of negotiating for meaning and this kind of correction can help learners notice their errors, create form-meaning connections and thus aid acquisition. Tomasello and Herron (1989) concluded that learners learn best when they generate a hypothesis and get immediate feedback. Accordingly, this creates the best condition under which learners may cognitively compare and contrast their own production to the target language. Horwitz (1988) also notes that a lot of learners are following their teachers' feedback for correctness and clarity of their productions, and in case they are not fed with explicit, clear, and well organized definitions, they feel more regressed.

The findings of (Han, 2019) suggest that learner engagement with written corrective feedback can be conceptualized as a process of perceiving and acting upon embedded learning opportunities afforded by WCF, and highlight the importance of establishing an alignment between affordances and learner agency to enhance individual students' engagement with written feedback.

An investigation was carried out by (Egi, 2010) to examine the relationship between learners' perceptions of recasts and their responses to the recasts. Twenty four foreign language learners of Japanese engaged in task- based interactions during which they received recasts of their errors. Each learner then watched video clips of the recast episodes and commented on them. Analysis was taken in relation to learners' responses to the recasts: uptake, repair, and modified output. In recast episodes where they produced uptake, their reports indicated that they perceived the recasts as corrective feedback significantly more frequently compared to cases where they did not produce uptake.

History of language and thought relationship can be easily traced in Sapir-Whorf hypothesis roughly implying the old story of chicken and egg. Regardless of the vicious nature of the circle and linguistic-determinism or relativism, these two are interwoven and mutually determining. People who speak different languages do indeed think differently and that even flukes of grammar can profoundly affect how we see the world. Language is a uniquely human gift, central to our experience of being human. But are languages merely tools for expressing our thoughts, or do they actually shape our thoughts?

Clearly, languages require different things of their speakers. Does this mean that the speakers think differently about the world? For some scholars, the answer to these questions has been an obvious yes. Certainly, speakers of different languages must attend to and encode strikingly different aspects of the world just so they can use their language properly. This suggests that patterns in a language can indeed play a causal role in constructing how we think. In practical terms, it means that when we are learning a new language, we are not simply learning a new way of talking, you are also inadvertently learning a new way of thinking. Beyond abstract or complex domains of thought like space and time, languages also meddles in basic aspects of how an issue be addressed.

Studies have found effects of language on how people construe events, reason about causality, keep track of number, understand material substance, perceive and experience emotion, reason about other people's minds, choose to take risks, and even in the way they choose professions and spouses. Taken together, these results show that linguistic processes are pervasive in most fundamental domains of thought, unconsciously shaping us from the nuts and bolts of cognition and perception to our loftiest abstract notions and major life decisions. Language is central to our experience of being human, and the languages we speak profoundly shape the way we think, the way we see the world, and the way we live our lives. 


\section{Proficiency level and perceptions}

Language proficiency has been subject to various scholarly and evolutionary studies to such an extent that a range of speculations starting from moderate versions such as weak version, strong version, divisible, indivisible, partially divisible to further hypotheses like "Two Mutually Exclusive" and then "Two Complementary" hypotheses have been suggested for (Oller \& Hinofotis, 1979). These inconsistencies compelled the scholars to raise further theories like "Hierarchical Skills Theory" (Sang et al., 1986) and so on. Nevertheless, recent attempts have been centered on relating the structure of language proficiency to its level (Vollmer, 1983; Hughes \& Porter, 1983; Alderson, 1986; Milanovic, 1988; Anivan, 1991, all cited in Abbasian, 2008). Regardless of the complexities, some have tried to associate one's world outlook with his language proficiency levels. In this respect, Rutherford and Sherwood Smith (1985) imply that the proficiency level of the learners is an effective factor influencing the perception the learners hold towards the type of instruction they receive. Ellis (2003) also presents that learners' language proficiency level affects their perspective towards corrective feedback they receive and consequently their learning and second language development.

Contrary to this trend, the way it affects and thereby shapes one's perceptions and belief system is a more complex phenomenon, if not more than the construct of language itself, phenomenon. So whether and the extent to which language type in itself and its proficiency levels may meddle in determining the teachers' and learners' perceptions of grammar instruction and the way corrective feedback can be given appear as an intact area and a great gap in the related literature. Assuming that language background plays role of a predictor, it might predict not only intergroup but intragroup perceptions. To fill this gap, four research questions addressing both types of perceptions and expressed in the form of corresponding null hypotheses were raised.

1. Does language background affect EFL learners' perceptions to explicit grammar instruction and corrective feedback?

2. Does language background affect EFL teachers' perceptions to explicit grammar instruction and corrective feedback?

3. Do teachers' and learners' perceptions towards explicit grammar instruction and corrective feedback significantly differ?

4. Does language proficiency level significantly affect EFL learners' perception to explicit grammar instruction and corrective feedback?

\section{Method}

\section{Participants}

The participants of the study were Iranian EFL teachers and learners. Totally 360 learners from two equally distributed linguistic backgrounds (i.e., 180 Azeri \& 180 Persian EFL learners) and 100 EFL teachers (50 Persian and 50 Azeri speakers), respectively, from the similar backgrounds participated in the study. The learners had already taken a version of the PET prior to attending their regular courses, which was used as the basis for dividing them into three proficiency levels. The teachers had been teaching in their affiliated institutes at least for one academic semester and had already attended TTC before starting their career. 


\section{Instruments}

The data collection instruments for the present study were two sets of already validated questionnaires (Baleghizadeh \& Firoozbakht, 2009) in two versions (one for the teachers and the other for the learners). Both were designed on a five-point scales (i.e., Likert format) with values ranging from agree strongly to disagree strongly. In order to facilitate the concept formation and understanding the core issue of each item the learners' version was translated into Persian. Of course, the majority of items on both questionnaires were similarly worded to permit later comparisons as it had been originally taken into account in the original versions of the questionnaires (Additional file 1).

\section{Design and procedure}

As a survey in design, this study was mainly conducted to explore interrelation between target variables. Though no treatment was rendered, the study sought to investigate the participants' opinions on instructional issue (i.e., explicit grammar instruction and corrective feedback). To do so, they received their respective questionnaires in order to express their views, which were statistically analyzed on the basis of non-parametric paradigm.

\section{Results}

\section{Investigation of the first research question (intragroup analysis)}

An analysis of chi-square was run to compare the learners' (i.e., Azeri and Persian EFL learners) perceptions towards the role of explicit grammar instruction and corrective feedback in learning English. The chi-square observed value is 44.39 (Table 1). This amount of chi-square value is higher than the critical value of 9.48 at 4 degrees of freedom, indicating that there are significant differences between them.

Table 2 displays the frequencies, percentages and the standardized residuals for the learners' perceptions. The percentages displayed on the second rows for each group signify that the Persian EFL learners (70.1\%) hold more positive views towards explicit grammar instruction and corrective feedback in learning English than the Azeri EFL learners do. On the other hand, 25.9\% of Azeri and 19.6 of Persian EFL learners hold negative views. Meanwhile, the Persian EFL learners are more undecided (10.3\%) than the Azeri EFL learners (6.8\%) are.

Although these percentages display the differences between the learners' perceptions, the standardized residuals show where the differences are statistically significant. Any standardized residuals beyond the plus and minus 1.96 ranges indicate significant differences between the two groups' perceptions (Fig. 1). Based on these indices, it can be concluded that the Persian EFL learners hold a less negative view than their Azeri counterparts towards the role of explicit grammar instruction and corrective feedback in learning English (Std. Residual = 2.8 and 2.8, respectively). Meanwhile, the Persian EFL learners hold a more neutral view (Std. Residual = 3.1) compared with the Std. Residual of -3.1 for the Azeri EFL learners. Therefore, the first null hypothesis that the

Table 1 Chi-Square analysis of the learners' perceptions towards the explicit grammar instruction and corrective feedback

\begin{tabular}{llcc}
\hline & Value & Df & Asymp. Sig. (2- sided) \\
\hline Pearson Chi-Square & $44.397^{\mathrm{a}}$ & 4 & .000 \\
\hline
\end{tabular}

a. 0 cells (.0\%) have expected count less than 5 . The minimum expected count is 231.50 
Table 2 Frequencies, percentages and standardized residuals of the perceptions towards explicit grammar instruction and corrective feedback

\begin{tabular}{|c|c|c|c|c|c|c|c|c|}
\hline & & & \multicolumn{5}{|l|}{ Choices } & \multirow[t]{2}{*}{ Total } \\
\hline & & & Strongly disagree & Disagree & Undecided & Agree & Strongly agree & \\
\hline \multirow{6}{*}{$\begin{array}{l}\text { Mother } \\
\text { Tongue }\end{array}$} & \multirow[t]{3}{*}{ AZERI } & Count & 279 & 421 & 185 & 988 & 829 & 2702 \\
\hline & & $\%$ & $10.3 \%$ & $15.6 \%$ & $6.8 \%$ & $36.6 \%$ & $30.7 \%$ & $100.0 \%$ \\
\hline & & Std. Residual & 1.9 & 2.8 & -3.1 & -1.0 & -.3 & \\
\hline & \multirow[t]{3}{*}{ PERSIAN } & Count & 218 & 312 & 278 & 1050 & 844 & 2702 \\
\hline & & $\%$ & $8.1 \%$ & $11.5 \%$ & $10.3 \%$ & $38.9 \%$ & $31.2 \%$ & $100.0 \%$ \\
\hline & & Std. Residual & -1.9 & -2.8 & 3.1 & 1.0 & .3 & \\
\hline \multirow[t]{2}{*}{ Total } & & Count & 497 & 733 & 463 & 2038 & 1673 & 5404 \\
\hline & & $\%$ & $9.2 \%$ & $13.6 \%$ & $8.6 \%$ & $37.7 \%$ & $31.0 \%$ & $100.0 \%$ \\
\hline
\end{tabular}

learners with different language backgrounds do not hold different perceptions to explicit grammar instruction and corrective feedback is rejected.

\section{Investigation of the second research question (intragroup analysis)}

An analysis of chi-square was run to compare the teachers' (i.e., Azeri and Persian EFL teachers) perceptions towards explicit grammar instruction and corrective feedback in teaching English. The chi-square observed value is 31.50 (Table 3). This amount of chi-square value is higher than the critical value of 9.48 at 4 degrees of freedom, indicating that there are significant differences between them.

Table 4 displays the frequencies, percentages and the standardized residuals for the teachers' perceptions. The percentages displayed on the second rows for each group signify that the Persian EFL teachers (59\%) showed more positive views than the Azeri counterparts (i.e., 51.1) towards explicit grammar instruction and corrective feedback. On the other hand, 32.2\% of Azeri and 26.3 of the Persian EFL teachers hold negative views towards. Meanwhile, the Persian and Azeri EFL teachers' hold almost the same neutral views.

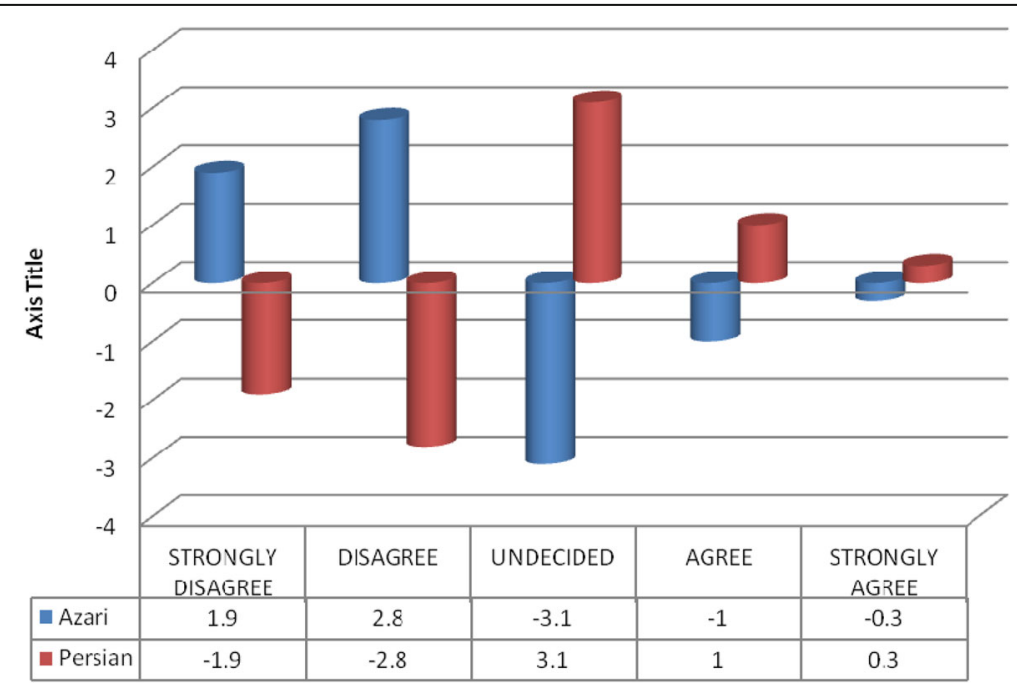

Fig. 1 standardized residuals of the perceptions towards explicit grammar instruction and corrective feedback 
Table 3 Chi-Square analysis of the teachers' perceptions towards explicit grammar instruction and corrective feedback

\begin{tabular}{llcc}
\hline & Value & Df & Asymp. Sig. (2-sided) \\
\hline Pearson Chi-Square & $31.503^{\mathrm{a}}$ & 4 & .000 \\
\hline
\end{tabular}

a. 0 cells $(.0 \%)$ have expected count less than 5 . The minimum expected count is 81.50

Although these percentages display the differences between the teachers' perceptions, the standardized residuals show where the differences are statistically significant. Any standardized residuals beyond the plus and minus 1.96 ranges indicate significant differences between the two groups' perceptions. Based on these indices, it can be concluded that the Persian EFL teachers hold a less negative views (Std. Residual $=-2.4$ ) than the Azeri EFL teachers (Std. Residual =2.4) do (Fig. 2). Meanwhile, the Persian EFL teachers hold a more positive view (Std. Residual =3) compared with the Std. Residual of -3 for the Azeri EFL teachers. Therefore, the second null hypothesis that language background does not affect the teachers' perceptions of explicit grammar instruction and corrective feedback is rejected.

\section{Investigation of the third research question (intergroup analysis)}

An analysis of chi-square was run to compare the EFL teachers' and learners' perceptions towards explicit grammar instruction and corrective feedback. The chi-square observed value is 102.84 (Table 5). This amount of chi-square value is higher than the critical value of 9.48 at 4 degrees of freedom, indicating that there are significant differences between the EFL teachers and learners' perceptions towards the variables.

Table 6 displays the frequencies, percentages and the standardized residuals for the teachers and learners' perceptions The percentages displayed on the second rows for each group signify that the EFL learners (68.7\%) show more positive views than their teachers (55.2) do. On the other hand, 29\% of EFL teachers and 22.8 of the learners hold negative views. Meanwhile, $15.5 \%$ of the EFL teachers are undecided compared with the $8.6 \%$ undecided learners.

Although these percentages display the differences between the EFL teachers and learners' perceptions, the standardized residuals show where the differences are

Table 4 Frequencies, percentages and standardized residuals of the teachers' perceptions towards explicit grammar instruction and corrective feedback

\begin{tabular}{|c|c|c|c|c|c|c|c|c|}
\hline & & & \multicolumn{5}{|l|}{ CHOICES } & \multirow[t]{2}{*}{ Total } \\
\hline & & & $\begin{array}{l}\text { STRONGLY } \\
\text { DISAGREE }\end{array}$ & DISAGREE & UNDECIDED & AGREE & $\begin{array}{l}\text { STRONGLY } \\
\text { AGREE }\end{array}$ & \\
\hline \multirow[t]{6}{*}{ Mother Tongue } & AZERI & Count & 76 & 117 & 98 & 212 & 97 & 600 \\
\hline & & $\%$ & $12.7 \%$ & $19.5 \%$ & $16.3 \%$ & $35.3 \%$ & $16.2 \%$ & $100.0 \%$ \\
\hline & & Std. Residual & -.6 & 2.4 & .5 & .8 & -3.0 & \\
\hline & PERSIAN & Count & 87 & 71 & 88 & 189 & 165 & 600 \\
\hline & & $\%$ & $14.5 \%$ & $11.8 \%$ & $14.7 \%$ & $31.5 \%$ & $27.5 \%$ & $100.0 \%$ \\
\hline & & Std. Residual & 6 & -2.4 & -.5 & -.8 & 3.0 & \\
\hline \multirow[t]{2}{*}{ Total } & & Count & 163 & 188 & 186 & 401 & 262 & 1200 \\
\hline & & $\%$ & $13.6 \%$ & $15.7 \%$ & $15.5 \%$ & $33.4 \%$ & $21.8 \%$ & $100.0 \%$ \\
\hline
\end{tabular}




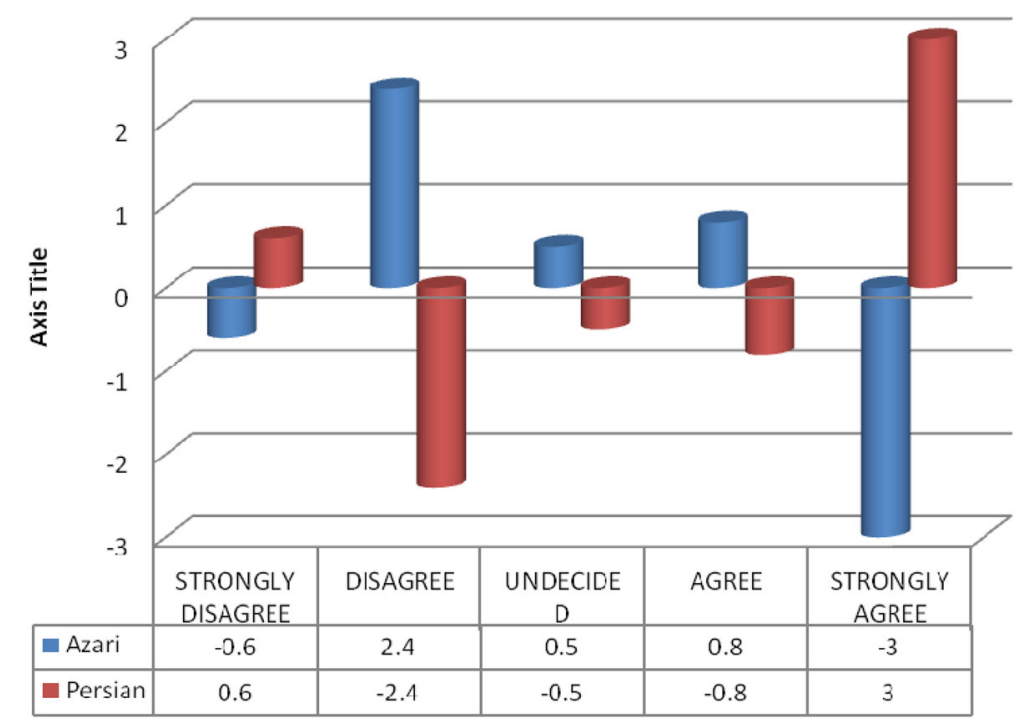

Fig. 2 Standardized residuals of the teachers' perceptions towards explicit grammar instruction and corrective feedback

statistically significant. Any standardized residuals beyond the plus and minus 1.96 ranges indicate significant differences between the two groups' perceptions. Based on these indices it can be concluded that the EFL learners hold a more positive than their teachers (i.e., Std. Residual $=2.3 \&-4.8$, respectively). Meanwhile, the teachers hold a more negative view (Std. Residual $=3.9)$ than their students (Std. Residual = 1.9) (Fig. 3). Therefore, the third null hypothesis that EFL teachers and learners do not hold different perceptions to the role of explicit grammar instruction and corrective feedback in learning English is rejected. That is to say, the EFL learners' and teachers' perceptions of the way instruction and correction to be rendered significantly vary and are less compatible.

\section{Investigation of the fourth research question (intragroup analysis)}

An analysis of chi-square was run to probe the effect of language proficiency level on EFL learners' perception to explicit grammar instruction and corrective feedback. As displayed in Table 7 the chi-square observed value is 61.20. This amount of chi-square value is higher than the critical value of 15.50 at 8 degrees of freedom, indicating that language proficiency level determines the perceptions towards grammar instruction type and corrective feedback.

As displayed in Table 8, all of the Std. Residuals are within the ranges of $+/-1.96$ but for the following five indices. The elementary group shows a significant disagreement (Std. Residual = 3.4) while the Std. Residual for the Advanced learners is - 3.5, i.e. they

Table 5 Chi-Square analysis of the teachers-learners' perceptions towards explicit grammar instruction and corrective feedback

\begin{tabular}{llcc}
\hline & Value & Df & Asymp. Sig. (2-sided) \\
\hline Pearson Chi-Square & $102.849^{\mathrm{a}}$ & 4 & .000 \\
\hline
\end{tabular}

a. 0 cells $(.0 \%)$ have expected count less than 5 . The minimum expected count is 117.93 
Table 6 Frequencies, percentages and standardized residuals of the teachers-learners' perceptions towards explicit grammar instruction and corrective feedback

\begin{tabular}{|c|c|c|c|c|c|c|c|c|}
\hline & & & \multicolumn{5}{|l|}{ Choices } & \multirow[t]{2}{*}{ Total } \\
\hline & & & Strongly disagree & Disagree & Undecided & Agree & Strongly agree & \\
\hline \multirow[t]{6}{*}{$\mathrm{JOB}$} & Learners & Count & 497 & 733 & 463 & 2038 & 1673 & 5404 \\
\hline & & $\%$ & $9.2 \%$ & $13.6 \%$ & $8.6 \%$ & $37.7 \%$ & $31.0 \%$ & $100.0 \%$ \\
\hline & & Std. Residual & -1.9 & -.8 & -3.0 & .9 & 2.3 & \\
\hline & Teachers & Count & 163 & 188 & 186 & 401 & 262 & 1200 \\
\hline & & $\%$ & $13.6 \%$ & $15.7 \%$ & $15.5 \%$ & $33.4 \%$ & $21.8 \%$ & $100.0 \%$ \\
\hline & & Std. Residual & 3.9 & 1.6 & 6.3 & -2.0 & -4.8 & \\
\hline \multirow[t]{2}{*}{ Total } & & Count & 660 & 921 & 649 & 2439 & 1935 & 6604 \\
\hline & & $\%$ & $10.0 \%$ & $13.9 \%$ & $9.8 \%$ & $36.9 \%$ & $29.3 \%$ & $100.0 \%$ \\
\hline
\end{tabular}

have expressed significantly less disagreement towards perception to explicit grammar instruction and corrective feedback.

The Std. Residual for the intermediate on selecting the "Disagree" choice is 2.1, i.e. the intermediate learners significantly disagree with explicit grammar instruction and corrective feedback. Considering the mid-point, i.e. "Undecided", the elementary learners are less undecided (Std. Residual $=-3.7)$ than the advanced learners (Std. Residual = 3.7) (Fig. 4).

It seems that the elementary learners are less undecided (6\% with a Std. Residual of - 3.7) than the advanced learners (6\% with a Std. Residual of 3.7) are. However, the chi-square value of 61.20 does not show any significant differences among the proficiency levels regarding their agreement with the explicit grammar instruction and corrective feedback. Rather, the differences lie in their disagreement towards the explicit grammar instruction and corrective feedback. As displayed in Table 8, more proficient learners express less disagreement with the explicit grammar instruction and corrective feedback $(3.4 \%$ for elementary, $2.1 \%$ for intermediate and $-3.5 \%$ for advanced learners). Furthermore, the elementary learners are less undecided (6\%) than the advanced learners (11.1\%). Therefore, the fourth null hypothesis addressing the effects of language proficiency in determining learners' perceptions towards grammar

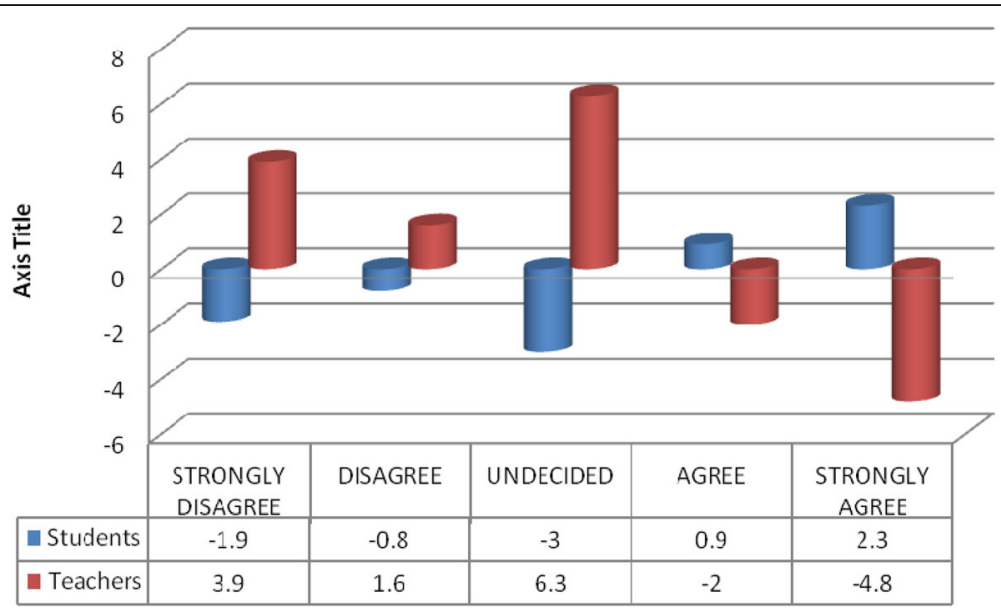

Fig. 3 Standardized residuals of the teachers-learners' perceptions towards explicit grammar instruction and corrective feedback 
Table 7 Explicit grammar instruction and corrective feedback by proficiency levels

\begin{tabular}{lllc}
\hline & Value & df & Asymp. Sig. (2-sided) \\
\hline Pearson Chi-Square & $61.205^{\text {a }}$ & 8 & .000 \\
\hline
\end{tabular}

a. 0 cells $(.0 \%)$ have expected count less than 5 . The minimum expected count is 154.13

instruction and corrective feedback is rejected since the elementary and intermediate learners show significant disagreement towards explicit grammar instruction and corrective feedback, while the advanced learners hold an opposite view (Fig. 4).

\section{Discussion}

The statistical analysis revealed that the first null-hypothesis was rejected. That is to say, the Persian EFL learners hold more positive views than the Azeri EFL learners. They also hold a more neutral view. The Persian EFL learners' positive views can be attributed to the linguistic background and the number of the languages they knew. The Persian EFL learners were bilinguals; however, the Azeri EFL learners were multilingual learners.

In a bid to link the findings to the literature, Hyland and Hyland's (2006) findings are supported as they believed "it is difficult to draw any clear conclusions and generalizations from the literature as a result of varied populations, treatments and research designs" (p. 84). Meanwhile, Krashen's (1982) pessimism towards corrective feedback is also sustained accordingly. He (1982) referred to corrective feedback as a serious mistake since it persuades learners to defend from themselves and because it only assists the development of learned knowledge and plays no role in acquired knowledge. Whereas, Long (1996) considered corrective feedback in the form of negotiating for meaning and this kind of correction can help learners notice their errors, create form-meaning connections and thus aid acquisition. This represents that different linguistic backgrounds can affect one's perception towards the second or foreign language and its different aspects.

Concerning the second null hypothesis, an analysis of chi-square proved that there were significant differences between the Azeri and Persian EFL teachers' perceptions

Table 8 Frequencies, percentages and standardized residuals of the efl learners' proficiency-based perceptions towards explicit grammar instruction and corrective feedback

\begin{tabular}{|c|c|c|c|c|c|c|c|}
\hline & & \multicolumn{5}{|l|}{ Choices } & \multirow[t]{2}{*}{ Total } \\
\hline & & Strongly disagree & Disagree & Undecided & Agree & Strongly agree & \\
\hline \multirow[t]{3}{*}{ Elementary } & Count & 209 & 232 & 108 & 672 & 580 & 1801 \\
\hline & $\%$ & $11.6 \%$ & $12.9 \%$ & $6.0 \%$ & $37.3 \%$ & $32.2 \%$ & $100.0 \%$ \\
\hline & Std. Residual & 3.4 & -.8 & -3.7 & -.3 & 1.0 & \\
\hline \multirow[t]{3}{*}{ Intermediate } & Count & 168 & 278 & 155 & 665 & 538 & 1804 \\
\hline & $\%$ & $9.3 \%$ & $15.4 \%$ & $8.6 \%$ & $36.9 \%$ & $29.8 \%$ & $100.0 \%$ \\
\hline & Std. Residual & .2 & 2.1 & .0 & -.6 & -.9 & \\
\hline \multirow[t]{3}{*}{ Advanced } & Count & 120 & 223 & 200 & 701 & 555 & 1799 \\
\hline & $\%$ & $6.7 \%$ & $12.4 \%$ & $11.1 \%$ & $39.0 \%$ & $30.9 \%$ & $100.0 \%$ \\
\hline & Std. Residual & -3.5 & -1.3 & 3.7 & .9 & -.1 & \\
\hline \multirow[t]{2}{*}{ Total } & Count & 497 & 733 & 463 & 2038 & 1673 & 5404 \\
\hline & $\%$ & $9.2 \%$ & $13.6 \%$ & $8.6 \%$ & $37.7 \%$ & $31.0 \%$ & $100.0 \%$ \\
\hline
\end{tabular}




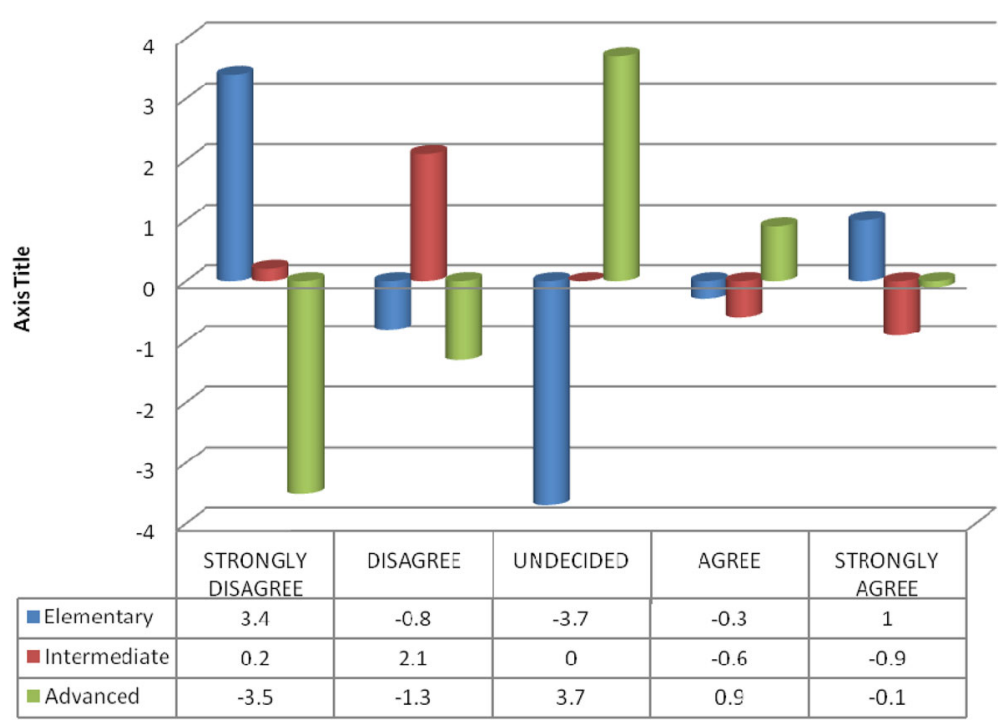

Fig. 4 Role language proficiency level in EFL learners' perceptions towards explicit grammar instruction and corrective feedback

towards the role of explicit grammar instruction and corrective feedback in learning English. The findings of the first two research questions might stress the effects of linguistic differences on EFL learners and teachers' perceptions of the role of explicit grammar instruction and corrective feedback. In another line of research, Borg (2006) puts forward the idea that teachers do indeed have a set of complex belief systems about the teaching grammar, and these are sometimes not reflected in their classroom practices for various complicated reasons. It is also believed that "teachers appear to see grammar as important for their learners and to have a sophisticated understanding of the problems and issues involved in its teaching" (Burgess \& Etherington, 2002, p.450). These findings are somehow in the same line with Persian EFL teachers' views in that they found that most of the teachers believed that grammar played a central role in language. Another support for Persian EFL teachers' view comes from a study that was done by Barnard and Scampton (2008).

Concerning the third hypothesis, the statistics revealed EFL teachers and learners hold highly different perceptions to the role of explicit grammar instruction and corrective feedback. That is to say, the EFL learners hold more positive views than the EFL teachers. This signifies that learners are more inclined towards the explicit instruction of grammar and the corrective feedback in the process of language learning.

The differences between teachers and learners attitudes can be attributed to their different views of language learning, communication and education. The differences also can be attributed to their language proficiency and lived experiences.

This is in line with what Schmidt (1994) stresses as the crucial role of explicit grammar formation in the second language development, and with what Doughty (2001) calls it as the "focal point" perspective of the learners while learning a new point in the grammar of the second language. Doughty's position, which is supported in the present study, then is in direct opposition to that of many teachers who believe that implicit attention should be given to form. On the other hand, the dual perspectives presented by the teachers and learners in the two Persian and Azeri contexts highlight that 
corrective feedback and explicit instruction might be holding different effects on the learners from different linguistically oriented backgrounds. Whether this difference is a matter of cultural background or not is a question which could be answered in a separate study.

Witnessing teachers with different and even opposing views towards employing corrective feedback has been recorded in the literature as something usual (Barnard \& Scampton, 2008; Borg \& Bums, 2008; Burgess \& Etherington, 2002). Hamouda (2011) points out that while teachers and learners share such common views about the importance of explicit teaching of grammatical points, there exist considerable discrepancies as to the techniques of explicit teaching and its nature. Diab (2006) also found various discrepancies between EFL instructors' and learners' preferences for explicit instruction of grammar and its error- correction techniques. Such differences between learners' and teachers' expectations and views about explicit instruction of grammar can result in unsatisfactory learning outcomes (Riazi \& Riasati, 2007; Katayama, 2007). It could be concluded that the ideas presented by learners and teachers either Azeri or Persian context go together, as the negative view towards the explicit instruction of grammar and corrective feedback was supported by the Azeri teachers as well as learners, while the positive perspective towards the issue was widespread among both teachers and learners in the Persian context.

Discrepancies explored with respect to the first three questions can also be traced in the language learning experiences both groups have had. English language learning is a third experience for the Azeri participants while it is the second for the Persian participants. Mainly the negative perceptions and perspectives of the former group may lie in their negative experiences of explicit grammar-dominant approach of Persian learning and teaching, though it deserves further empirical investigations.

The fourth null-hypothesis was rejected on the grounds that the statistically significant chi-square value computed showed differences in their disagreement towards the explicit grammar instruction and corrective feedback. It means that the proficiency level of the learners is an effective factor influencing the perception they hold towards the type of instruction they receive and the way the corrective feedback affects their learning and second language development.

\section{Conclusion}

As a flash-back, the findings are generally in line with both theoretical and empirical findings as highlighted in the notions like mental images, thoughts raised by Abbasian (2009), the interpretative frames and learning-teaching maxims of Richards (1996), hidden agenda of Nunan (1989). Furthermore, Howrwitz's, Fronhlinch et al's (1985) and Mangubhai et al. (1998) claims that "teacher had understanding and beliefs about CLT that differed from those of CLT researchers and theorists" among many others are sustained.

In sum, it is concluded that not only there are so many areas of intragroup variations and differences as to the type of instruction in general and grammar one in particular as well as the desirable error correction and corrective feed-backing approaches among the learners and teachers obviously in light of language background types, but there are enormous areas intergroup differences. Moreover, it is proved that level of language proficiency plays a part along with the construct itself in setting the perspectives and 
perceptions concerning either explicit or implicit teaching of grammatical points. In case of the corrective feedback also learners presented significant relationship between language proficiency level and tendency to be benefited from explicit corrective feedback.

The findings are rather significant in that the differences are mainly attributed to the language learning experiences both groups in general and the Azeri participants have had in the Iranian setting. Having been exposed to primarily explicit Persian grammar instruction and feed-backing approach, the Azeri participants' mainly negative outlooks of the variables seem to originate from the Persian language learning experiences as a second language, while English language learning is a second experience for the Persian speakers.

\section{Additional file}

Additional file 1: Appendix A. Learners' Questionnaire. Appendix B: Teachers' Questionnaire (DOCX 14 kb)

Acknowledgements

We would like to appreciate all the participants of the study.

Funding

The study did not receive any funding.

Availability of data and materials

Please contact the corresponding author for requesting the data.

\section{Authors' contributions}

Mr. Mohammadi collected and analyzed the data. Dr. Yousefi discussed the results. Both are equally accountable for all aspects of the work and read and approved the final manuscript.

\section{Competing interests}

The authors declare that they have no competing interests.

\section{Publisher's Note}

Springer Nature remains neutral with regard to jurisdictional claims in published maps and institutional affiliations.

Received: 3 December 2018 Accepted: 15 April 2019

Published online: 27 May 2019

\section{References}

Abbasian, GR. (2009). ELT educational context, teacher intuition, and learner hidden agenda: a study of conflicting maxims. TELL, Journal of Teaching English Language and Literature Society of Iran. Vol. 3, No. 9, Winter 2009.

Abbasian, Gh.R. (2008). Language construct and education as matters of proficiency level (a practical approach). Reflecting on Insights from ELT Research: Selected papers from the $4^{\text {th }}$ international ELT Research Conference: 26-28 May, 2005, Canakkale, $18^{\text {th }}$ Match University, Turkey.

Alderson, J. C. (1986). Innovations in language testing? In M. Portal (Ed.), Innovations in language testing. NFRE-Nelson: Windsor.

Anivan, S. (1991). Current developments in language testing (pp. 1-19). Singapore: SEAMEO Regional language Center.

Baleghizadeh, S., \& Firoozbakht, S. (2009). Gender differences in learners' and teachers' perceptions of the role of grammar instruction and corrective feedback. Shahid Beheshti University: Applied Linquistics Journal, 2(1), 28-26.

Barnard, R., \& Scampton, D. (2008). Teaching grammar: A survey of EAP teaching in New Zealand. New Zealand Studies in Applied Linguistics, 14(2), 59-82.

Borg, S. (2006). Teacher cognition and language education: Research and practice. London: Continuum.

Borg, S., \& Bums, A. (2008). Integrating grammar in adult TESOL classrooms. Applied Linguistics, 29(2), 456-482.

Burgess, J., \& Etherington, S. (2002). Focus on grammatical form: Explicit or implicit? System, 30, 433-458.

Diab, L. R. (2006). University students' beliefs about learning English and French in Lebanon. System, 34, 80-96.

Doughty, C. (2001). Cognitive underpinnings of focus on form. Cambridge: Cambridge University Press.

Doughty, C., \& Williams, J. (1998). Pedagogical choices in focus on form. In C. Doughty \& J. Williams (Eds.), Focus on form in classroom second language acquisition (pp. 197-261). New York: Cambridge University Press.

Egi, T. (2010). Uptake, modified output, and learner perceptions of recasts: Learner responses as language awareness. The Modern Language Journal, 94, 1-22.

Ellis, R. (2003). Task-based language learning and teaching. Oxford: Oxford University Press.

Eslami-Rasekh, Z., \& Fatahi, A. (2004). Using meta-pragmatic instruction to improve advanced EFL learners' pragmatic awareness. TESL EJ, 8 (2) A2, 1-12 
Frohlich, M., et al. (1985). Differences in the communicative orientation of L2 classrooms. TESOL Quarterly, 19, 51-62. Hammerly, H. (1985). An integrated theory of language teaching. N. Burnaby, BC, Canada: Second Language Publications. Hammond, R. M. (1988). Accuracy versus communicative competency: The acquisition of grammar in the second language classroom. Hispania, 71, 408-417.

Hamouda, A. (2011). A study of learners and teachers' preferences and attitudes towards correction of classroom written errors in Saudi EFL context. English Language Teaching, 4 (3), 138-143.Retreived November 20, 2011, from http://www. ccsenet.org/elt.

Han, Y. (2019). Written corrective feedback from an ecological perspective: The interaction between the context and individual learners. System. 80, 288-303.

Hendrickson, J. M. (1978). Corrective feedback in foreign language teaching: Recent theory, research, and practice. Modern Language Journal, 62, 387-398.

Higgs, T. V., \& Clifford, R. (1982). The push toward communication. In T. v. Higgs (Ed.), curriculum competence, and the foreign language teacher (pp. 57-79). Skokie, IL: National Textbook.

Horwitz, E.K. (1987). Surveying student beliefs about language learning. In A.L., Wenden \& J., Rubin (Eds.). Learner strategies in language Learning. Prentice-Hall, Englewood Cliffs, NJ, pp.119-129.

Horwitz, E. K. (1988). The beliefs about Language Learning of Beginning University Foreign Language Learners. Modern Language Journal, 72, 3283-3294.

Hudson, R. (2001). Grammar teaching and writing skills: the research evidence. Syntax in the schools, 17, 1-6.

Hyland, K., \& Hyland, F. (2006). Feedback in Second Language Writing: Contexts and Issues. New York: Cambridge University Press.

Jing, H. (2006). Learner research in metacognitive training? An example of mismatch between learner and teacher agenda. $p$. 99, Language Teaching Research, 10(1), 95-117.

Katayama, A. (2007). Japanese EFL learners' preferences toward correction of classroom oral errors. Asian-EFL-journal, 9(4), 135-151. Retrieved October 5, 2011, form http://www.asian-efl-journal.com/Dec_2007_ak.php.

Krashen, S. D. (1982). Principles and practice in second language acquisition. New York: Pergamum Institute of English Retrieved June 20, 2011 from: http://www.sdkrashen.com/Principles_and_Practice/index.html.

Krashen, S. D. (1985). The input hypothesis: issues and implications. New York: Longman.

Lalande, J. F. (1982). Reducing composition errors: An experiment. Modern Language Journal, 66, 140-149.

Lightbown, P. M. (1998). The importance of timing in focus on form. In C. Doughty \& J. Williams (Eds.), focus on form in classroom second language acquisition (PP. 177-196). Newyork: Cambridge University Press.

Lightbown, P. M., \& Spada, N. (1999). How languages are learned. Oxford, UK: Oxford University Press.

Lingli, D., \& Wannaruk, A. (2010). The effects of explicit and implicit instruction in English refusals. Chinese Journal of Applied Linguistics (Bimonthly), 33(3), 318-337.

Long, M. (1996). The role of linguistic environment in second language acquisition. In W. C. Ritchie \& B. K. Bahtia (Eds.), Handbook of second language acquisition (pp. 413-468). New York: Academic Press.

Long, M., \& Robinson, P. (1998). Focus on Form: Theory, Research, and Practice. In C. Doughty \& J. Williams (Eds.), Focas on Form in Classroom Second Language Acquisition (pp. 15-41). Cambridge: Cambridge.

Lyster, R., Lightbown, P. M., \& Spada, N. (1999). A response to Truscott's "what's wrong with oral grammar correction". The Canadian Modern Language Review, 55, 457-467.

Mangubhai, F. et al. (1998). Primary LOTE teachers' understandings and beliefs about CLT: report on the first phase. Toowoonba, QLD: Centre for Research into Language Teaching Methodologies, The Natural languages and Literary Institute of Australia.

Milanovic, M. (1988). The construct validation of a performance based battery of English language progress test. Ph.D. thesis. University of London.

Nunan, D. (1989). Hidden agenda: The role of the learner in programme implementation. In R.K., Johnson (Ed.). The Second Language Curriculum. OUP. 176-86.

Nunan, D. (1995). Closing the gap between learning and instruction. TESOL Quarterly, 29(1), 133-188.

Oller, J.W. \& Hinofotis, F.B. (1979). Two mutually exclusive hypotheses about second language ability: Factor analytic studies of a variety of language tests. Paper presented at the annual meeting of the linguistic Society of America, December, 1976.

Riazi, A., \& Riasati, M. (2007). Language learning style preferences: A learner's case study of ShirazEFLinstitutes.AsianEFJJournal. linkinghub.elsevier.com/retrieve/pii/S1877042810020355.

Richards, J. C. (1996). Teachers' maxims in language teaching. p.1, TESOL Quarterly, 30(2), 281-296.

Rutherford, W., \& Sharwood Smith, M. (1985). Consciousness-Raising and Universal Grammar. Applied Linguistics, 6, $274-282$.

Sang, F., et al. (1986). Models of second language competence: A structural equation approach. Language Testing, 3(1), 54-79.

Schmidt, R. (1994). In N. Ellis (Ed.), Implicit and explicit learning of languages Implicit learning and the cognitive unconscious (pp. 165-209). New York: Academic Press.

Schmidt, R. W. (1990). The role of consciousness in second language learning. Applied Linguistics, 11, 128-158.

Schulz, R. A. (2001). Cultural differences in student and teacher perceptions concerning the role of grammar instruction and corrective feedback: USA-Colombia. Modern Language Journal, 85(2), 244-258.

Semke, H. D. (1984). Effects of the red pen. Foreign Language Annals, 17, 195-202.

Swain, M. (1985). Communicative competence: Some roles of comprehensible input and comprehensible output in its development. In S. M. Gass \& C. G. Madden (Eds.), Input in second language acquisition (pp. 235-253). Rowley, MA: Newbury House.

Swain, M. (2005). The output hypothesis: Theory and research. In E. Hinkel (Ed.), Handbook of research in second language teaching and learning (pp. 35-52). Mahwah, NJ: Lawrence Erlbaum Associates.

Swain, M., \& Lapkin, S. (1995). Problems in output and the cognitive processes they generate: A step towards second language learning. Applied Linguistics, 16(3), 371-391.

Terrell, T. D. (1977). A natural approach to second language acquisition and learning. Modern Language Journal, 61, $325-336$.

Tomasello, M., \& Herron, C. (1989). Feedback for language transfer errors: The Garden Path technique. Studies in Second Language Acquisition, 11, 385-395. 
Truscott, J. (1999). The case for "the case for grammar correction in L2 writing classes": A response to Ferris. Journal of Second Lanquage Writing, 8, 111-122.

Valette, R. M. (1991). Proficiency and the prevention of fossilization-An editorial. Modern Language Journal, 75, 325-328.

Vollmer, H. J. (1983). The structure of foreign language competence. In A. Hughes \& D. Porter (Eds.), Current developments in language testing (pp. 3-30). UK: University of Reading.

Wenden, A. L. (1986). What do second language learners know about their language learning? A second look at retrospective accounts. Applied linguisyics (pp. 7187-7201).

Submit your manuscript to a SpringerOpen ${ }^{\circ}$ journal and benefit from:

- Convenient online submission

- Rigorous peer review

- Open access: articles freely available online

- High visibility within the field

- Retaining the copyright to your article

Submit your next manuscript at $\boldsymbol{\nabla}$ springeropen.com 